\title{
Hubungan Perilaku Merokok Sebelum Tidur Dengan Kejadian Insomnia Pada Remaja Laki-Laki Di Dusun Bolor Sembe Desa Rarang Batas Tahun 2019
}

\author{
Mansur Junaidi 1), Muh Amrullah ${ }^{1 \text { ** }}$ \\ Email: aam.dais.ad@gmail.com \\ ${ }^{1)}$ Universitas Qamarul Huda Badarrudin Bagu
}

\begin{abstract}
ABSTRAK
Perilaku merokok merupakan perilaku yang membakar salah satu produk tembakau yang dimaksudkan untuk dibakar, dihisap dan/atau dihirup termasuk rokok kretek, rokok putih, cerutu atau bentuk lainnya. Perokok di masyarakat Indonesia ternyata tidak hanya di kalangan dewasa saja, tetapi juga pada remaja. Perilaku merokok laki-laki dan perempuan umumnya pertama kali dilakukan ketika memasuki masa remaja. Prevalensi penduduk Indonesia usia 15 tahun ke atas yang merokok tiap hari sebesar $28,2 \%$. Secara nasional. Ketergantungan nikotin menyebabkan seorang perokok harus menghisap rokok terus-menerus dan menimbulkan berbagai akibat terhadap tubuh, salah satunya adalah insomnia. Metode penelitian yang di pakai pada penelitian ini adalah analitik korelational dengan pendekatan cross sectional dengan jumlah sample sebanyak 63 orang dengan teknik pengambilan sample total sampling uji statistik menggunakan chi-square. Dari 63 sample yang akan di teliti peneliti hanya mendapatkan 52 responden penelitian 11 responden tidak memenuhi kriteri penelitian, setelah di lakukan uji statistik menggunakan chi-square di dapatkan nilai $\mathrm{p}$ value atau sig (2-tailed) $=$ 0.03 . hasil di peroleh bahwa nilai $\mathrm{p}$ value $<$ a signifikan $(0.03<0.05)$. Terdapat hubungan yang signifikan antara perilaku merokok sebelum tidur dengan kejadian insomnia pada remaja lakilaki di Dusun Bolor Sembe Desa Rarang Batas Tahun 2019.
\end{abstract}

Kata Kunci : Insomnia, Perilaku Merokok, Remaja.

\begin{abstract}
Smoking behavior is the behavior of respondents who describe smoking activities that can be seen from the stage of smoking behavior, smoking intensity, smoking time. Smoker in indonesia society trun out not only to adults, but also to adolescents. Smoking behavior of men and women is generally first done when entering adolescence. The prevalence of indonesia population aged 15 year and over who smoke every day is $28 \%$. Nationally. Nicotine dependence cause a smoker to have to smoke cigarettes continuously and cause various effects on the body, one of which is insomnia. There is a relationship between smoking behavior before sleeping with the incidence of insomnia in teenage boys in bolor sembe village 2019. To know the relationship of smoking behavior before sleeping with the ocurrence of insomnia in teenage boys in bolor sembe village 2019. The research method used in this study is cerrelational analytic with cross sectional approach with a total sample of 63 people with total sampling technique of statistical test using chi-square. From 63 sample that were examined by research criteria, after doing a statistical test using chi-square, the $\mathrm{p}$ value or sig (2-tailed) $=$ 0,03 was obtained. the results show that the $\mathrm{p}$ value $<\mathrm{a}$ significant $(0,03<0,05)$. There is relationship but a sufficient relationship between smoking behavior before going to sleep with the incidence of insomnia in adolecent boys in bolor sembe village 2019 .
\end{abstract}

Keywords: smoking behavior, insomnia, teenagers. 


\section{A. LATAR BELAKANG}

Indonesia menempati urutan ketiga di dunia dengan jumlah perokok terbanyak setelah Cina 300 juta, India 120 juta, dan Indonesia sendiri 82 juta. Menurut data WHO (2011), 34,8\% (59.900.000) dari populasi orang dewasa di Indonesia saat ini mengkonsumsi rokok. Sedangkan pada remaja, WHO (2011) menunjukkan bahwa 67\% remaja di Indonesia pertama kali merokok pada usia 15 tahun. Prevalensi perokok pada kalangan remaja usia 15-19 tahun laki-laki berjumlah 37,3\% dan perempuan berjumlah $3,1 \%$, dimana jumlah tersebut mengalami peningkatan dalam 13 tahun dari $7,1 \%$ pada tahun 2001 menjadi $18,3 \%$ pada tahun 2013 [1].

Nusa Tenggara Barat sendiri berada di urutan ke enam untuk Presentase tertinggi nasional usia pertama kali merokok terdapat pada usia 15-19 tahun 43,3\%, 20-24 tahun $14,6 \%$. Penduduk yang pertama kali merokok pada usia 15-19 tahun tertinggi di Maluku Utara 51,9\%, Riau 49,5\%, Sumatera Selatan 47,7\%, dan Kepulauan Riau 47,7\%. Perokok yang berumur $>15$ tahun di Nusa Tenggara Barat mencapai $35,5 \%$, masing-masing perokok aktif $30,5 \%$, perokok kadang- kadang $5,0 \%$, berhenti merokok 3,2\% dan menghisap rata-rata 10 batang per hari sebanyak 42,6\% [2].

Pengaruh nikotin dalam rokok dapat membuat seseorang menjadi pecandu atau ketergantungan pada rokok. Remaja yang sudah kecanduan merokok tidak dapat menahan keinginan untuk tidak merokok, mereka cenderung sensitif terhadap efek dari nikotin. Ketergantungan nikotin menyebabkan seorang perokok harus menghisap rokok terus-menerus dan menimbulkan berbagai akibat terhadap tubuh, salah satunya adalah insomnia. Insomnia merupakan gangguan untuk memperoleh keadaan tidur yang maksimal, baik dari segi kualitas maupun kuantitas. Insomnia adalah gangguan tidur berupa kesulitan untuk memulai tidur, kesulitan untuk mempertahankan tidur atau bangun tidur pagi dengan perasaan tidak puas tidur [3].
Adapun dampak yang di timbulkan oleh insomnia pada remaja adalah insomnia akan menyebabkan rasa mengantuk sepanjang hari. Mengantuk itu sendiri merupakan faktor resiko terjadinya kecela-kaan, mudah jatuh, penurunan stamina pada seseorang, Selain itu dampak yang bisa di rasakan oleh pelajar sendiri adalah merasa mengantuk dan sulit berkonsentrasi saat pelajaran sedang berlangsung, akibat dari kesulitan tidur pada malam hari, tampak tidak segar dan tidak bersemangat saat mengikuti kegiatan belajar mengajar di kelas [4].

Dari hasil studi pendahuluan yang di lakukan oleh peneliti dengan metode wawancara langsung dengan responden sebanyak 16 orang remaja, ternyata dari 16 orang remaja 9 orang remaja tersebut memiliki kebiasaan merokok sebelum memulai tidur di malam hari, 4 orang remaja mengatakan kadang-kadang jika ada rokok dan 3 mengatakan dan mengatakan jarang merokok sebelum tidur, responden juga mengatakan kebiasaan yang mereka lakukan adalah begadang di malam hari dengan memulai tidur di atas jam 11 malam, Berdasarkan hasil studi pendahuluan oleh peneliti maka peneliti tertarik untuk meneliti Hubungan Kebiasaan Merokok Sebelum Tidur Dengan Kejadian Insomnia Pada Remaja Di Dusun Bolor Sembe Desa Rarang Batas Kecamtan Terara Kabupaten Lombok Timur 2019.

\section{B. METODE PENELITIAN}

Desain penelitian yang di gunakan adalah analitik korelational dengan pendekatan cross sectional populasi pada penelitian ini adalah 63 orang dengan jumlah sample yang di gunakan adalah 63 orang dengan teknik pengambilan sample dengan total sampling, uji statistik yang di gunakan adalah chi-square untuk melihat apakah ada hubungan antara perilaku merokok remaja sebelum tidur dengan kejadian insomnia pada remaja di dusun bolor sembe desa rarang batas tahun 2019. Jika $p$ value $<$ a signifikan maka ada hubungan antara kedua variabel tersebut, jika $p$ value > a signifikan maka tidak 
terdapat hubungan antara kedua variabel tersebut.

\section{HASIL DAN PEMBAHASAN}

Tabel 1

Distribusi Responden Berdasar Umur Pengelompokan Remaja

\begin{tabular}{ccc}
\hline Remaja & $\mathrm{n}$ & $\%$ \\
\hline Remaja Awal & 14 & 26.9 \\
Remaja Tengah & 25 & 48.1 \\
Remaja Akhir & 13 & 25.0 \\
\hline Total & 52 & 100.0 \\
\hline
\end{tabular}

Tabel 2

Distribusi Responden Berdasar Tingkat Pendidikan

\begin{tabular}{ccc}
\hline Pendidikan & $\mathrm{n}$ & $\%$ \\
\hline Smp/Mts & 20 & 38.5 \\
Smk/Sma & 32 & 61.5 \\
\hline Total & 52 & 100.0 \\
\hline
\end{tabular}

Tabel 3

Distribusi Perilaku Merokok Remaja Sebelum Tidur

\begin{tabular}{ccc}
\hline Perilaku Merokok & $\mathrm{n}$ & $\%$ \\
\hline Ringan & 4 & 7.7 \\
Sedang & 30 & 57.7 \\
Berat & 18 & 34.6 \\
\hline Total & 52 & 100.0 \\
\hline
\end{tabular}

Tabel 4

Distribusi Kejadian Insomnia Pada Responden

\begin{tabular}{ccc}
\hline Kejadian Insomnia & $\mathrm{n}$ & $\%$ \\
\hline Tidak Insomnia & 24 & 46.2 \\
Insomnia & 28 & 53.8 \\
\hline Total & 52 & 100.0 \\
\hline
\end{tabular}

Tabel 5

Distribusi Hubungan Perilaku Merokok Sebelum

Tidur Dengan Kejadian Insomnia Responden

\begin{tabular}{ccccr}
\hline Perilaku & \multicolumn{2}{c}{ Suminsomnia } & Total \\
\cline { 2 - 4 } Merokok & Tidak Insomnia & Insomnia & \\
\hline Ringan & 3 & 1 & 4 & d \\
& $75.0 \%$ & $25.0 \%$ & $100.0 \%$ & m \\
Sedang & 17 & 13 & 30 & e \\
& $56.7 \%$ & $43.3 \%$ & $100.0 \%$ \\
Berat & 4 & 14 & 18 & 2 \\
& $22.2 \%$ & $77.8 \%$ & $100.0 \%$ \\
\hline Total & 24 & 28 & 52 \\
& $46.2 \%$ & $53.8 \%$ & $100.0 \%$ \\
\cline { 2 - 4 } & & &
\end{tabular}

\section{Pembahasan}

\section{Perilaku merokok}

Berdasarkan data hasil penelitian yang telah di lakukan oleh peneliti di dapatkan sebagian responden atau Remaja yang menjadi sample memiliki perilaku merokok sedang. Salah satu yang yang menyebabkan responden berada pada perilaku merokok sedang tentunya seperti yang telah di sampaikan bahwa perilaku merokok sedang ini bisa di akibatkan oleh usia memulai merokok sehingga memiliki kebiasaan merokok yang tidak bisa di lupakan di karenakan kecanduan akan nikotin itu sendiri, seperti yang di sampaikan oleh Kemala pada 2007 [3].

Pada umumnya perilaku merokok pada remaja semakin lama akan semakin meningkat sesuai dengan tahap perkembangannya yang ditandai dengan meningkatnya frekuensi dan intensitas merokok, serta sering mengakibatkan mereka mengalami ketergantungan nikotin. Pengaruh nikotin dalam rokok dapat membuat seseorang menjadi pecandu atau ketergantungan pada rokok. Remaja yang sudah kecanduan merokok tidak dapat menahan keinginan untuk tidak merokok, mereka cenderung sensitif terhadap efek dari nikotin. Ketergantungan nikotin menyebabkan seorang perokok harus menghisap rokok terus- menerus dan menimbulkan berbagai akibat terhadap tubuh, salah satunya adalah insomnia (Sanchi, 2009) dalam vaora [3].

Hasil penelitian yang pernah di lakukan oleh Fuadah [5] dan Elita [6]. Membuktikan sebagian besar dari remaja mempunyai tipe perilaku merokok sedang. Semakin muda orang mulai merokok kemungkinan untuk berhenti merokok akan lebih rendah karena efek ketergantungan yang diakibatkan nikotin di dalam rokok, apabila dilakukan penghentian merokok secara mendadak akan menimbulkan efek seperti gemetar, keluar keringat, cepat marah, cemas, frustasi dan insomnia.

\section{Kejadian insomnia}

Berdasarkan hasil penelitian di dapatkan kejadian insomnia yang di alami oleh responden endiri paling banyak adalah insomnia sebanyak 
28 orang (53.8\%), salah satu yang menjadi penyebab insomnia sendiri adalah perilaku merokok yang mana menurut Kairupan [4]. Secara garis besar ada berbagai macam faktor yang menyebabkan insomnia, salah satunya adalah merokok, dimana kandung-an nikotin didalam rokok dapat mengacau-kan pola tidur seseorang yang membuat penggunanya selalu waspada dan terjagaselain itu penyebab insomnia, salah satu penyebabnya adalah nikotin pada rokok yang termasuk dalam kelompok zat stimuli yang menekan saraf pusat pada manusia.

Gangguan tidur/insomnia pada remaja dipengaruhi berbagai faktor baik medis maupun nonmedis. Penelitian di Jepang oleh Ohida dkk pada tahun (2004) dalam mushoffa, dkk. (2013). Menunjukkan beberapa faktor risiko terjadinya gangguan tidur, yaitu jenis kelamin, siswa tingkat SMU, dan gaya hidup yang tidak sehat (stres psikologis, merokok dan minum alkohol). Berdasarkan hasil penelitian didapatkan data bahwa mayoritas responden mengalami insomnia yakni sebanyak 28 orang (53.8\%), dan Tidak insomnia sebanyak 24 orang (46.2\%).

Menurut Luis, dkk. [7] data insomnia sendiri pada tahun (2010) dari 300,452 juta penduduk Indonesia terdapat 28,053 juta orang $(11,7 \%)$ Indonesia yang mengalami gangguan tidur dimana sekitar $10 \%$ dialami oleh kalangan remaja. Jenis gangguan tidur yang dialami sebagian besar orang adalah insomnia (80\%) dan hipersomnia (15\%). Kesulitan untuk memulai tidur, sering terbangun di malam hari dan sulit untuk tertidur kembali serta terbangun di pagi hari dengan keadaan tidak segar adalah gejala klasik dari insomnia.

\section{Hubungan perilaku merokok sebelum tidur dengan kejadian insomnia}

Uji statistik dari kedua variabel yaitu perilaku merokok sebelum tidur dengan kejadian insomnia dengan uji statistik chisquare dengan tingkat kemaknaan 95\% ( $a=$ $0,05)$, di katakan memiliki hubungan jika $p<a$ $(0,05)$ dan tidak memiliki hubungan jika $p>a$ $(0,05)$. Peneliti menggunakan bantuan komputer
Spss versi 22 dan setelah di lakukan pengolahan di dapatkan hasil $p=0.03$ dan di katakan kedua variabel memiliki hubungan, kemudian di cari arah korelasi dan keeratan hubungan menggunakan person product moment di dapatkan nilai person product moment positif sebesar $(0,365)$ sehingga arah korelasinya adalah positif sedangkan untuk keeratan hubungan kedua variabel memiliki hubungan yang cukup yaitu nilai 0,365 berada di antara $0,25-0,5$ atau korelasi cukup.

Dari hasil tersebut dapat di jelaskan bahwa perilaku merokok sebelum tidur dengan kejadian insomnia memiliki hubungan namun hubungan yang lemah dengan $p$ sebesar (0.033) $<$ a (0.05), dan nilai person product moment sebesar $(0,365)$ karena nilai $p<a$ maka terdapat hubungan yang cukup antara perilaku merokok sebelum tidur dengan kejadian insomnia pada remaja laki-laki di dusun bolor sembe. berdasarkan hasil uji statistik maka bisa di katakan perilaku merokok/merokok sebeluum tidur memiliki hubungan dengan kejadian insomnia seperti yang di sampaikan oleh (Dewi 2013 dalam Nurlia [8]) faktor yang menyebabkan insomnia di antaranya Stress, Kelainan-kelainan kronis, Efek samping pengobatan, Pola makan yang buru, Kafein, dan alkohol, Kurang berolah raga,Merokok.

Pengaruh nikotin dalam rokok dapat membuat seseorang menjadi pecandu atau ketergantungan pada rokok. Remaja yang sudah kecanduan merokok tidak dapat menahan keinginan untuk tidak merokok, mereka cenderung sensitif terhadap efek dari nikotin. Ketergantungan nikotin menyebabkan seorang perokok harus menghisap rokok terus-menerus dan menimbulkan berbagai akibat terhadap tubuh, salah satunya adalah insomnia. Insomnia merupakan gangguan untuk memperoleh keadaan tidur yang maksimal, baik dari segi kualitas maupun kuantitas [3].

\section{E. KESIMPULAN}

Sebagian besar responden memiliki perilaku merokok sedang sebelum tidur sebanyak 30 
orang $(57.7 \%)$ di mana ada beberapa hal yang bisa menjadi pemicu responden memiliki perilaku merokok sedang salah satunya adalah biasanya setelah mencoba rokok pertama, individu tersebut akan menjadi ketagihan untuk merokok. Prevalensi merokok meningkat sesuai dengan penambahan umur. Hal ini dapat dikatakan bahwa pada usia 16 tahun hampir dikatakan remaja telah mengkonsumsi rokok.

Sebagaian besar responden mengalami insomnia sebanyak 28 orang (53.8\%) dari perilaku merokok yang di lakukan sebelum tidur insomnia sendiri dapat berpengaruh terhadap timbulnya banyaknya penyakit akan timbul jika tidak segera di atasi, insomnia sendiri memang dapat di sebabkan oleh stres, gangguan pola makan, jarang olah raga, ketergantungan obat, kafein dan yang terakhir adalah merokok seperti yang telah di jelaskan.

Hasil uji statistik dengan uji chi-square di dapatkan hasil $p$ value sebesar $=0.03<\alpha=$ 0.05 , dan nilai keeratan korelasinya di dapatkan sebesar 0,365 maka antara perilaku merokok sebelum tidur dengan kejadian insomnia pada remaja laki-laki di dusun bolor sembe memiliki hubungan cukup. Artinya antara kedua variabel ini memiliki hubungan cukup di mana perilaku merokok yang di lakukan oleh remaja memiliki hubungan yang cukup terhadap kejadian insomnia pada remaja di Dusun Bolor Sembe.

\section{DAFTAR PUSTAKA}

[1] Riskesdas. (2014). Presentasi Wakil Menteri Kesehatan: Upaya Pengendalian Tembakau di Indonesia. Jakarta: Departemen Kesehatan Republik Indonesia.

[2] Badan Penelitian dan Pengembangan Kesehatan Kementerian Kesehatan RI. Hasil Utama RISKESDAS 2018. Januari 2019.

[3] Vaora, M., Sabrian, F., \& Dewi, Y. I. (2014). Hubungan Kebiasaan Merokok Remaja Dengan Gangguan Pola Tidur. Jurnal Keperawatan Jiwa, 2 (1), 58-66.
[4] Kairupan, J. A., Rottie, J., \& Malara, R. (2016). Hubungan Merokok Dengan Kejadian Insomnia. Ejournal Keperawatan (E-Kp), 4 (1), 1-8.

[6] Elita, Eliana. 2014. Gambaran Perilaku Merokok Pada Mahasiswa Program Studi Ilmu Keperawatan Fakultas Kedokteran Dan Ilmu Kesehatan Universitas Muhammadiyah Yogyakarta Angkatan 2010-2013. Skripsi. Yogyakarta : Program studi ilmu keperawatan.

[6] Fuadah, Maziyyatul. 2011. Gambaran Faktor-Faktor Yang Mempengaruhi Perilaku Merokok Pada Mahasiswa LakiLaki. Skripsi. Depok : Fakultas Ilmu Keperawatan Universitas Indonesia.

[7] Luis, P., Silvana, D. M., \& Sapariah, A. (2018). Perbandingan Kualitas Tidur Siswa/Siswi. Stikes Suaka Insan Banjarmasin, 6 (2), 1-6.

[8] Nurlia, 2016.Pengaruh tidur sehat dengan terhadap tingkat Insomnia Lansia.Skripsi, Program Studi keperawatan fakultas kedokteran dan ilmu kesehatan: Universitas islam negeri Salauddin makasar. 